\title{
MANAGEMENT OF ENDOCRINE DISEASE Residual adrenal function in Addison's disease
}

\author{
Simon H S Pearce ${ }^{11,2}$, Earn H Gan ${ }^{1,2}$ and Catherine Napier ${ }^{2}$ \\ ${ }^{1}$ Translational and Clinical Research Institute, Newcastle University, Newcastle, UK and ${ }^{2}$ Endocrine Unit, Royal \\ Victoria Infirmary, Newcastle upon Tyne Hospitals NHS Foundation Trust, Newcastle, UK
}

Correspondence should be addressed to S H S Pearce

Email

simon.pearce@ncl.ac.uk

\begin{abstract}
Over the last 10 years, evidence has accumulated that autoimmune Addison's disease (AAD) is a heterogeneous disease. Residual adrenal function, characterised by persistent secretion of cortisol, other glucocorticoids and mineralocorticoids is present in around $30 \%$ of patients with established AAD, and appears commoner in men. This persistent steroidogenesis is present in some patients with AAD for more than 20 years, but it is commoner in people with shorter disease duration. The clinical significance of residual adrenal function is not fully clear at the moment, but as it signifies an intact adrenocortical stem cell population, it opens up the possibility of regeneration of adrenal steroidogenesis and improvement in adrenal failure for some patients.
\end{abstract}

\section{Introduction}

Autoimmune Addison's disease (AAD) is one of the least common autoimmune endocrine conditions, affecting around 1 in 8000 individuals of European ancestry, with a moderate predilection for women (F:M ratio 1.5:1) (1, $2,3)$. It is characterised by progressive destruction of the steroid-secreting cells of the adrenal cortex, driven in around $85 \%$ of cases by an immune response targeted at steroid 21-hydroxylase, and other steroidogenic enzymes $(4,5)$. The onset of steroidogenic failure in AAD may be slow. An initial asymptomatic phase is characterised by autoimmune destruction of cells in both adrenal cortices but no hormonal deficit; this is followed by a period of compensated adrenal failure in which circulating renin and ACTH are elevated but with normal circulating steroid hormones, and a potential increase in skin and mucous membrane pigmentation; and latterly by a symptomatic phase of reduced basal and stimulated corticosteroid secretion $(6,7)$.

There are several notable clinical points about the evolution of disease. First, AAD may have a prolonged compensated phase, with one case report demonstrating a gap of 9 years from the onset of pigmentation, indicating elevated circulating ACTH, to a diagnosis of AAD (8). Post-mortem studies from the 1930s identified areas of adrenocortical hyperplasia as well as areas of destruction and fibrosis in patients with fatal $\operatorname{AAD}(9,10)$. This leads to the idea that in evolving AAD the autoimmune destruction is balanced by an ACTH-driven compensatory hypertrophy which may lead to this gradual decline in adrenocortical function in some patients (7). Secondly, it is well documented that mineralocorticoid deficiency may proceed glucocorticoid deficiency $(11,12)$. It has been proposed that the high concentrations of cortisol in the zona fasciculata may protect it, to some degree, from immune attack $(6,7)$. The normal zona fasciculata may have cortisol concentrations between 10 and $50 \mu \mathrm{M}$ (13), which would be sufficient to produce anergy or apoptosis of antigen-presenting cells in vitro. Mineralocorticoids do not have the same potent immunosuppressive effects, which might leave the zona glomerulosa more 
vulnerable to immune attack. Lastly, patients entering the latter stages of disease have very high circulating ACTH concentrations, typically for months. This means that when challenged with a synacthen (tetracosactrin) test, there is typically minimal rise $(\leq 10 \%)$ in the serum cortisol concentration, as the adrenals are already maximally stimulated by endogenous ACTH secretion.

Historically, it has been assumed that AAD is a homogenous disease with regards adrenal steroidogenic function and that without lifelong glucocorticoid and mineralocorticoid replacement medication the disease is invariably fatal. However, several case reports of spontaneous recovery and long-term steroid-independence in welldocumented AAD patients have raised the prospect that the outlook is not the same for everybody with $\operatorname{AAD}(14,15$, 16). There is increasing evidence to suggest preservation of endogenous adrenal steroidogenesis (hereafter referred to as 'residual adrenal function') in some patients, even years after AAD diagnosis, and we review the recent advances in our understanding of this phenomenon in this article.

\section{What is residual adrenal function?}

Current thinking is that the destructive autoimmune process in Addison's disease progresses to a point of no return where complete adrenocortical steroidogenic failure is inevitable and universal. However, following their observation of a male AAD patient who appeared to spontaneously recover adrenal function following 7 years of conventional steroid replacement (14), Smans and Zelissen studied 27 patients with established AAD for signs of residual adrenocortical function (17). Participants' regular hydrocortisone and fludrocortisone was stopped for $24 \mathrm{~h}$ and substituted for dexamethasone, and the serum cortisol response to synacthen was measured by immunoassay. While none of these patients had a normal cortisol response, 10 (37\%) did show detectable serum cortisol concentrations, with one patient having a peak value of $100 \mathrm{nmol} / \mathrm{L}(3.62 \mathrm{\mu g} /$ $\mathrm{dL})$, suggesting that low level, residual adrenal function might not be uncommon (17). These studies have recently been extended by three different groups using mass spectrometric steroid metabolome assays in a further 249 individuals with established AAD (Table 1) $(18,19,20)$.

In summary, these three additional studies have used more sensitive assays to establish beyond doubt that AAD patients are heterogeneous in terms of adrenal function, with around 30\% having some low level, residual adrenal steroidogenesis for many years following diagnosis. In the two largest studies around $10 \%$ had detectable serum cortisol concentration $\geq 100 \mathrm{nmol} / \mathrm{L}$ and $5 \%$ had concentrations $\geq 150 \mathrm{nmol} / \mathrm{L}(19,20)$. Residual adrenal function comprised not just glucocorticoid secretion, but residual mineralocorticoid secretion was also found in many patients (Fig. 1), as might be predicted by the known sequence of adrenocortical cell migration (see subsequently). In contrast, preserved adrenal androgen secretion was not frequent, and indeed because of preserved gonadal steroid secretion, was technically more difficult to evaluate. All studies found that the glucocorticoid precursor 11-deoxycortisol, either in serum or urine, correlated strongly with serum cortisol concentration, making it a potentially useful marker of residual adrenal steroidogenesis that might be ascertained in patients who continued to take their regular medications $(18,19,20)$. Interestingly, 6 of 84 participants with residual function had AAD for 20 or more years $(19,20)$, suggesting that it is a durable state in some patients, although overall residual steroidogenesis was commoner in patients with shorter disease duration. One patient had originally been studied in 2012, 4 years after presentation with AAD when she had a peak stimulated serum cortisol of $184 \mathrm{nmol} / \mathrm{L}(6.7 \mu \mathrm{g} / \mathrm{dL})$;

Table 1 Summary of studies of residual adrenal function (RAF) in AAD.

\begin{tabular}{|c|c|c|c|c|c|}
\hline Reference & $\begin{array}{l}\text { Method of } \\
\text { steroid assay }\end{array}$ & $\begin{array}{c}\text { AAD } \\
\text { patients, } n\end{array}$ & RAF, $\boldsymbol{n}(\%)$ & $\begin{array}{c}\text { Serum cortisol } \\
>100 \mathrm{nmol} / \mathrm{L}^{*}, n(\%)\end{array}$ & Comment \\
\hline Smans \& Zelissen (17) & $\mathrm{SCl}$ & 27 & $10(39 \%)$ & $1(4 \%)$ & On dexamethasone \\
\hline Vulto et al. (18) & Serum LC-MS & 20 & $10(50 \%)$ & $-\dagger$ & Hydrocortisone not omitted \\
\hline Napier et al. (19) & SCl; urine LC-MS & 37 & $6(16 \%)$ & $5(14 \%)$ & $\begin{array}{l}36 \text { h without replacement } \\
\text { medication }\end{array}$ \\
\hline Saevik et al. (20) & Serum LC-MS & 192 & $58(30 \%)$ & $19(10 \%)$ & $\begin{array}{l}18 \text { h without replacement } \\
\text { medication }\end{array}$ \\
\hline Total & - & 276 & $84(30 \%)$ & $25 / 256(10 \%)$ & \\
\hline
\end{tabular}




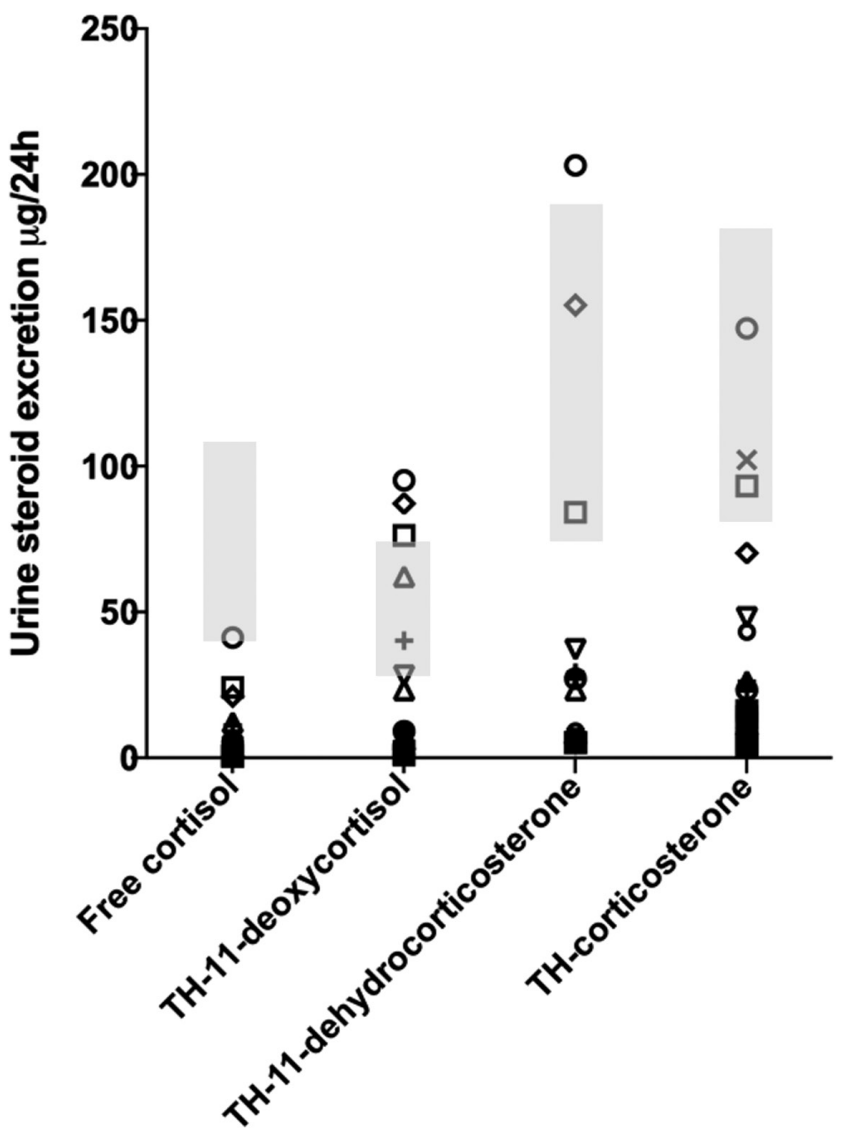

Figure 1

Urine corticosteroid excretion for 37 patients with

autoimmune Addison's disease in a medication-free state (19). Each patient is represented by the same symbol across each metabolite, including the glucocorticoids: free cortisol and tetrahydro-11-deoxycortisol (THS); and the mineralocorticoids: tetrahydro-11-dehydrocorticosterone (THA) and tetrahydrocorticosterone (THB). Grey bars represent interquartile ranges from healthy individuals.

repeat measurement in 2016 showed a concentration of $252 \mathrm{nmol} / \mathrm{L}(9.1 \mu \mathrm{g} / \mathrm{dL})(19,21)$. Another notable finding was that residual adrenal function was found in more than $40 \%$ (33 of 76) of men with AAD in the largest study (20), whereas it was found in just 18\% (2 of 11) in another (19) (the third study did not specify). Lastly, residual adrenal function did not correlate with lack of adrenal crisis or improved quality of life (20).

\section{Adrenocortical plasticity and adrenal cell turnover}

For more than 80 years, it has been known that subcapsular enucleation of the adrenal gland in rodents results in regeneration of adrenal mass in 4-6 weeks $(22,23,24)$, with detectable steroidogenic function as early as 8 days following enucleation in rats $(22,23,24)$. Early on, administration of exogenous glucocorticoid following adrenal enucleation was observed to inhibit adrenocortical regrowth and to suppress steroidogenesis (22). This was the first indication that both adrenal size and steroidogenic function are primarily maintained by secretion of ACTH from the pituitary gland. During chronic exogenous steroid therapy in man (e.g. prednisolone), ACTH is suppressed leading to adrenal atrophy and functional adrenal failure if exogenous steroids are withdrawn rapidly. In a complementary fashion, excessive pituitary ACTH secretion during Cushing's disease leads to adrenal gland hyperplasia, as well as hypersecretion of glucocorticoid. Similarly, in the inherited defects of the steroidogenic enzymes, the high ACTH levels promote adrenal growth: a series of conditions collectively termed congenital adrenal hyperplasia.

Knowledge about the cell biology of adrenal zonation and steroidogenesis in human is imperfect, largely because there are significant differences between human and rodent adrenal morphology and secretory function that preclude confident cross-species extrapolations. Nevertheless, the widely accepted model suggests that adrenocortical stem cells (ACSC), which have a subcapsular location, proliferate and differentiate into cells that have the ability to manufacture and secrete steroid hormones under the influence of ACTH $(25,26)$. Following proliferation, the daughter cells migrate centripetally while undergoing a zone-specific differentiation programme (26). First they transit through the zona glomerulosa, taking on an aldosterone secreting phenotype. Then into the zona fasciculata where they secrete cortisol and finally they end up in the innermost cortical zone, the zona reticularis where they secrete adrenal androgens. There is a terminal apoptotic layer at the border between the zona reticularis and the adrenal medulla. Cell migration, studied with thymidine autoradiography, suggest that the passage from the subcapsular region to apoptotic layer takes about 100 days in the rat (27). However, recent cell tracking studies using transgenic murine models suggests sex-specific rates of adrenocortical turnover, with a repopulation time of 9 months in adult males compared to just 3 months in female mice (28). Interestingly, similar finding have been made in neonatal mice (29) and there appears to be an androgen-dependent inhibition of stem cell proliferation in both these models. These animal studies form a framework to understand more about human adrenocortical plasticity. Furthermore, the sex differences 
in adrenocortical turnover may also be relevant to the higher prevalence of residual adrenal function found in men with AAD.

\section{Residual adrenal function in context of autoimmunity}

Numerous autoimmune conditions exhibit waxing and waning disease activity, usually referred to as a relapsing and remitting course, typified by Graves' hyperthyroidism or multiple sclerosis (30). This contrasts to type 1 diabetes (T1D), in which the autoimmune destruction appears persistent and relentless. Nevertheless, persistent insulin secretion, characterised by differing C-peptide concentrations endures in many individuals (31). Interestingly, a recent large study of Scottish patients with T1D found that persistent C-peptide secretion was also commoner in males (32), paralleling the findings in AAD (28).

It has been largely assumed that autoimmunity in AAD eventually leads to the destruction of all adrenocortical function (6). However, these recent findings demonstrate that complete destruction of steroidogenic function does not occur in a substantial minority of AAD patients. This could reflect that the autoimmune process itself may remit over time $(6,11)$. In addition, residual adrenal function persisting for many years must be underpinned by intact ACSC function and we speculate that these cells may be spared autoimmune destruction as they do not express steroid 21-hydroxylase, or other steroidogenic enzymes which are the target of the immune attack $(4,33,34)$. A durable, albeit perhaps reduced, ACSC population has the potential to proliferate indefinitely and repopulate the adrenal cortex, particularly if the autoimmune process is checked by immunomodulatory medication or remits naturally. This possibility stimulated us to perform a series of small experimental medicine studies to try and improve steroidogenic function in AAD (Table 2) $(21,35,36)$.

\section{Could residual adrenal function be exploited to cure AAD?}

Most patients presenting for the first time with AAD have circulating cortisol concentrations that, despite being abnormal, are easily detectable with conventional immunoassays. We found a median serum cortisol of $125 \mathrm{nmol} / \mathrm{L}(4.5 \mu \mathrm{g} / \mathrm{dL})$ in twenty individuals at the time of AAD presentation, with only three of 20 having levels below an arbitrary $24 \mathrm{nmol} / \mathrm{L}(0.9 \mu \mathrm{g} / \mathrm{dL})$ limit of quantitation (19). This clearly demonstrated that patients with AAD have ongoing steroidogenesis at the time of diagnosis and we wished to explore whether this could be rescued. We treated 13 newly diagnosed AAD patients using a combination of high dose depot synacthen, in order to maintain trophic stimulation of steroidogenesis, and the B lymphocyte depleting agent rituximab in an attempt to combat the immune attack (36). No patient fully recovered adrenal function but $50 \%$ of participants had some improvement in steroidogenic function, leaving 4 (30\%) including 2 men, with detectable serum cortisol of $99 \mathrm{nmol} / \mathrm{L}(3.6 \mu \mathrm{g} / \mathrm{dL})$ or more, after 18 months (Table 2) (36). This rate of residual adrenal function is greater than that found spontaneously in the observational studies, where only $10 \%$ of individuals had serum cortisol concentrations $\geq 100 \mathrm{nmol} / \mathrm{L}(17,18,19,20)$.

Could adrenal steroidogenesis be salvageable further into the course of the disease? With this question in mind, we administered high dose synacthen to 13 unselected patients with AAD established for more than a year (21). Two patients who both had a residual adrenal function, with baseline serum cortisols of 184 and $219 \mathrm{nmol} / \mathrm{L}$, responded by augmenting their steroidogenesis enough to stop replacement medication (21). In one patient the steroidogenesis slowly decreased once synacthen injections were ceased, but the other participant remained off medication for 8 years. Although only a transient benefit was found for one of the patients, this remains

Table 2 Summary of interventional studies in AAD.

\begin{tabular}{|c|c|c|c|c|c|}
\hline Reference & Cohort & Intervention & $\begin{array}{c}\text { AAD } \\
\text { patients, } n\end{array}$ & Outcome & Comment \\
\hline Pearce et al. (35) & Newly diagnosed AAD & Rituximab & 6 & $\begin{array}{l}1 \text { patient }(17 \%) \\
\text { steroid-free at } 1 \text { year }\end{array}$ & $\begin{array}{l}\text { Peak serum cortisol } \\
434 \mathrm{nmol} / \mathrm{L} ; \text { Adrenal } \\
\text { failure returned }\end{array}$ \\
\hline Napier et al. (36) & Newly diagnosed AAD & $\begin{array}{l}\text { Rituximab and } \\
\text { Synacthen }\end{array}$ & 13 & $\begin{array}{l}4 \text { patients }(30 \%) \text { with peak } \\
\text { serum cortisol } \geq 99 \mathrm{nmol} / \mathrm{L} \\
\text { at } 18 \text { month }\end{array}$ & $\begin{array}{l}\text { No patient was able to } \\
\text { stop replacement } \\
\text { medication }\end{array}$ \\
\hline Gan et al. (21) & Established AAD & Synacthen & 13 & $\begin{array}{l}2 \text { patients (15\%) became } \\
\text { medication free }\end{array}$ & $\begin{array}{l}\text { One patient remained } \\
\text { steroid independent } \\
\text { for } 8 \text { years }\end{array}$ \\
\hline
\end{tabular}


the promise of residual adrenal function and additional studies, particularly in those with highest residual steroidogenesis and an insidious onset, are now needed to target this small but important group of AAD patients who might reap great benefit from new approaches. This leads on to quantitative questions about the significance of different degrees of residual adrenal function.

\section{Can we define useful residual adrenal steroidogenic function?}

Patients with T1D and C-peptide concentrations above $200 \mathrm{pmol} / \mathrm{L}$ have been demonstrated to have lower rates of microvascular complications and reduced hypoglycaemia (37). However, even those with lesser degrees of endogenous insulin secretion also have improved outcomes, including lower glycosylated haemoglobin, lower insulin requirement and reduced urine albumin excretion (38). Therefore, two key unresolved questions are what defines residual adrenal function; and whether at a certain level residual steroidogenesis might be of clinical benefit for AAD patients? In two of the recent studies, mass spectrometric analysis was able to quantitate serum cortisol down to concentrations of $<0.01$ and $0.9 \mathrm{nmol} / \mathrm{L}$, respectively $(18,20)$, whereas, in the third study, urine cortisol was quantified down to $3 \mathrm{nmol} / \mathrm{L}$ (19). However, these very low corticosteroid levels may be neither physiologically relevant nor indeed reflect true adrenal cortisol production, as extra-adrenal cortisol generation is reported from many tissues including intestine, thymus, lung, skin and brain $(39,40)$. In the largest observational studies of AAD patients $(19,20)$, only around $10 \%$ had detectable serum cortisol concentration $\geq 100 \mathrm{nmol} / \mathrm{L}$, with $5 \%$ having concentrations $\geq 150 \mathrm{nmol} / \mathrm{L}$. This means that although the residual adrenal function was commoner than expected, in most AAD patients the mechanism by which it could be contributing to their health is not obvious at the moment. Moreover, reduced frequency or lack of adrenal crisis might be an obvious possible correlate of residual adrenal function, given that symptoms of adrenal crisis predominantly relate to mineralocorticoid deficiency, there may not be a direct relation between it and residual cortisol secretion. A much larger study is now necessary to find out whether the few patients with residual steroidogenesis in the top centiles of steroid production have some associated health benefit.

\section{Conclusions}

Residual adrenal function, characterised by detectable but low concentrations of cortisol and other corticosteroids, is present in around $30 \%$ of AAD patients. However, only around $5-10 \%$ have serum cortisol concentrations over $100-150 \mathrm{nmol} / \mathrm{L}$ which might potentially be associated with some clinical benefit, although it seems most likely that too few individuals in this category have currently been studied to fully characterise this. Serum or urine 11-deoxycortisol may be a sensitive marker for residual adrenal function. Owing to adrenocortical stem cell plasticity, patients with residual adrenal function are important subjects for further study to see if the promise of a surviving pluripotent stem cell population can be exploited to enhance steroidogenesis and ameliorate adrenocortical failure.

\section{Declaration of interest}

The authors declare that there is no conflict of interest that could be perceived as prejudicing the impartiality of this review.

\section{Funding}

Original work on this subject has been funded by Medical Research Council grants MR/J002526/1, G0900001 and G07017632. Additional infrastructure support was made available through the National Institute for Health Research (NIHR) Newcastle Biomedical Research Centre based at Newcastle Hospitals NHS Foundation Trust and Newcastle University, the Newcastle Clinical Research Facility, and Roger and Virginia Robotham. S P has received speaker fees from Sanofi, Quidel and Berlin Chemie, and has consulted for Apitope BV.

\section{Acknowledgements}

The authors are grateful to Dr Anna Mitchell and Kathleen Allinson for contributing to these studies, Prof Wiebke Arlt, Dr Angela Taylor, Dr Lorna Gilligan and the Birmingham University Steroid Metabolome Analysis Core, as well as all the patients who were willing participants.

\section{References}

1 Husebye ES, Allolio B, Arlt W, Badenhoop K, Bensing S, Betterle C, Falorni A, Gan EH, Hulting AL, Kasperlik-Zaluska A et al. Consensus statement on the diagnosis, treatment and follow-up of patients with primary adrenal insufficiency. Journal of Internal Medicine 2014275 104-115. (https://doi.org/10.1111/joim.12162)

2 Løvås K \& Husebye ES. High prevalence and increasing incidence of Addison's disease in western Norway. Clinical Endocrinology 200256 787-791. (https://doi.org/10.1046/j.1365-2265.2002.t01-1-01552.x)

3 Pazderska A \& Pearce SH. Adrenal insufficiency: recognition and management. Clinical Medicine 201717 258-262. (https://doi. org/10.7861/clinmedicine.17-3-258) 
4 Winqvist O, Karlsson FA \& Kämpe O. 21-Hydroxylase, a major autoantigen in idiopathic Addison's disease. Lancet 1992339 1559-1562. (https://doi.org/10.1016/0140-6736(92)91829-w) 5 Erichsen MM, Løvås K, Skinningsrud B, Wolff AB, Undlien DE, Svartberg J, Fougner KJ, Berg TJ, Bollerslev J, Mella B et al. Clinical, immunological, and genetic features of autoimmune primary adrenal insufficiency: observations from a Norwegian registry. Journal of Clinical Endocrinology and Metabolism 200994 4882-4890. (https:// doi.org/10.1210/jc.2009-1368)

6 Betterle C, Dal Pra C, Mantero F \& Zanchetta R. Autoimmune adrenal insufficiency and autoimmune polyendocrine syndromes: autoantibodies, autoantigens, and their applicability in diagnosis and disease prediction. Endocrine Reviews 200223 327-364. (https://doi. org/10.1210/edrv.23.3.0466)

7 Mitchell AL \& Pearce SH. Autoimmune Addison disease: pathophysiology and genetic complexity. Nature Reviews: Endocrinology 20128 306-316. (https://doi.org/10.1038/ nrendo.2011.245)

8 Torrejón S, Webb SM, Rodríguez-Espinosa J, Martínez de Osaba MJ \& Corcoy R. Long-lasting subclinical Addison's disease. Experimental and Clinical Endocrinology and Diabetes 2007115 530-532. (https:// doi.org/10.1055/s-2007-973077)

9 Guttman PH. Addison's disease: a statistical analysis of five hundred and sixty-six cases and a study of the pathology. Archives of Pathology $193010742-785$.

10 Saphir O \& Binswanger H. Suprarenal cortical insufficiency and cytotoxic contraction of the suprarenals. JAMA 193095 1007-1011. (https://doi.org/10.1001/jama.1930.02720140029007)

11 Betterle C, Scalici C, Presotto F, Pedini B, Moro L, Rigon F \& Mantero F. The natural history of adrenal function in autoimmune patients with adrenal autoantibodies. Journal of Endocrinology 1988 117 467-475. (https://doi.org/10.1677/joe.0.1170467)

12 Harris PE \& Kendall-Taylor P. Isolated aldosterone deficiency in a patient with autoimmune adrenalitis. American Journal of Medicine 199190 124. (https://doi.org/10.1016/0002-9343(91)90515-y)

13 Dickerman Z, Grant DR, Faiman C \& Winter JS. Intraadrenal steroid concentrations in man: zonal differences and developmental changes. Journal of Clinical Endocrinology and Metabolism 198459 1031-1036. (https://doi.org/10.1210/jcem-59-6-1031)

14 Smans LC \& Zelissen PM. Partial recovery of adrenal function in a patient with autoimmune Addison's disease. Journal of Endocrinological Investigation 200831 672-674. (https://doi. org/10.1007/BF03345623)

15 Chakera AJ \& Vaidya B. Spontaneously resolving Addison's disease. OJM 2012105 1113-1115. (https://doi.org/10.1093/qjmed/hcr162)

16 Baxter M, Gorick S \& Swords FM. Recovery of adrenal function in a patient with confirmed Addison's disease. Endocrinology, Diabetes and Metabolism Case Reports 20132013 130070. (https://doi.org/10.1530/ EDM-13-0070).

17 Smans LC \& Zelissen PM. Does recovery of adrenal function occur in patients with autoimmune Addison's disease? Clinical Endocrinology 201174 434-437. (https://doi.org/10.1111/j.13652265.2010.03944.x)

18 Vulto A, Bergthorsdottir R, van Faassen M, Kema IP, Johannsson G \& van Beek AP. Residual endogenous corticosteroid production in patients with adrenal insufficiency. Clinical Endocrinology 201991 383-390. (https://doi.org/10.1111/cen.14006)

19 Napier C, Allinson K, Gan EH, Mitchell AL, Gilligan LC, Taylor AE, Arlt W \& Pearce SHS. Natural history of adrenal steroidogenesis in autoimmune Addison's disease following diagnosis and treatment. Journal of Clinical Endocrinology and Metabolism 2020105 dgaa187. (https://doi.org/10.1210/clinem/dgaa187)

20 Sævik ÅB, Åkerman AK, Methlie P, Quinkler M, Jørgensen AP, Höybye C, Debowska AJ, Nedrebø BG, Dahle AL, Carlsen S et al. Residual corticosteroid production in autoimmune Addison disease.
Journal of Clinical Endocrinology and Metabolism 2020105 dgaa256. (https://doi.org/10.1210/clinem/dgaa256)

21 Gan EH, MacArthur KDR, Mitchell AL, Hughes BA, Perros P, Ball SG, James RA, Quinton R, Chen S, Furmaniak J et al. Residual adrenal function in autoimmune Addison's disease: improvement following tetracosactide $\left(\mathrm{ACTH}_{1-24}\right)$ treatment. Journal of Clinical Endocrinology and Metabolism 201499 111-118. (https://doi.org/10.1210/jc.20132449)

22 Ingle DJ \& Higgins GM. Regeneration of the adrenal gland following enucleation. American Journal of the Medical Sciences 1938196 232-239. (https://doi.org/10.1097/00000441-193808000-00012)

23 Greep RO \& Deane HW. Histological, cytochemical and physiological observations on the regeneration of the rat's adrenal gland following enucleation. Endocrinology 194945 42-56. (https://doi.org/10.1210/ endo-45-1-42)

24 Ennen WB, Young BKL \& Engelend WC. Zone-specific cell proliferation during adrenocortical regeneration after enucleation in rats. American Journal of Physiology: Endocrinology and Metabolism 2005 289 E338-E391. (https://doi.org/10.1152/ajpendo.00031.2005)

25 Pignatelli D, Ferreira J, Vendeira P, Magalhães MC \& Vinson GP. Proliferation of capsular stem cells induced by ACTH in the rat adrenal cortex. Endocrine Research 200228 683-691. (https://doi. org/10.1081/erc-120016987)

26 Lerario AM, Finco I, LaPensee C \& Hammer GD. Molecular mechanisms of stem/progenitor cell maintenance in the adrenal cortex. Frontiers in Endocrinology 20178 52. (https://doi.org/10.3389/ fendo.2017.00052)

27 Zajicek G, Ariel I \& Arber N. The streaming adrenal cortex: direct evidence of centripetal migration of adrenocytes by estimation of cell turnover rate. Journal of Endocrinology 1986111 477-482. (https:// doi.org/10.1677/joe.0.1110477)

28 Grabek A, Dolfi B, Klein B, Jian-Motamedi F, Chaboissier MC \& Schedl A. The adult adrenal cortex undergoes rapid tissue renewal in a sex-specific manner. Cell Stem Cell 201925 290.e2-296.e2. (https:// doi.org/10.1016/j.stem.2019.04.012)

29 Dumontet T, Sahut-Barnola I, Septier A, Montanier N, Plotton I, Roucher-Boulez F, Ducros V, Lefrançois-Martinez AM, Pointud JC, Zubair $\mathrm{M}$ et al. PKA signaling drives reticularis differentiation and sexually dimorphic adrenal cortex renewal. JCI Insight 20183 e98394. (https://doi.org/10.1172/jci.insight.98394)

30 Codaccioni JL, Orgiazzi J, Blanc P, Pugeat M, Roulier R \& Carayon P. Lasting remissions in patients treated for Graves' hyperthyroidism with propranolol alone: a pattern of spontaneous evolution of the disease. Journal of Clinical Endocrinology and Metabolism 198867 656-662. (https://doi.org/10.1210/jcem-67-4-656)

31 Oram RA, McDonald TJ, Shields BM, Hudson MM, Shepherd MH, Hammersley S, Pearson ER, Hattersley AT \& UNITED Team. Most people with long-duration type 1 diabetes in a large populationbased study are insulin microsecretors. Diabetes Care 201538 323-328. (https://doi.org/10.2337/dc14-0871)

32 McKeigue PM, Spiliopoulou A, McGurnaghan S, Colombo M, Blackbourn L, McDonald TJ, Onengut-Gomuscu S, Rich SS, A Palmer CN, McKnight JA et al. Persistent C-peptide secretion in Type 1 diabetes and its relationship to the genetic architecture of diabetes. BMC Medicine 201917 165. (https://doi.org/10.1186/s12916-0191392-8)

33 Rottembourg D, Deal C, Lambert M, Mallone R, Carel JC, Lacroix A, Caillat-Zucman S \& le Deist F. 21-Hydroxylase epitopes are targeted by CD8 $\mathrm{T}$ cells in autoimmune Addison's disease. Journal of Autoimmunity 201035 309-315. (https://doi.org/10.1016/j. jaut.2010.07.001)

34 Dawoodji A, Chen JL, Shepherd D, Dalin F, Tarlton A, Alimohammadi M, Penna-Martinez M, Meyer G, Mitchell AL, Gan EH et al. High frequency of cytolytic 21-hydroxylase-specific CD8+ T cells in autoimmune Addison's disease patients. Journal 
of Immunology 2014193 2118-2126. (https://doi.org/10.4049/ jimmunol.1400056)

35 Pearce SHS, Mitchell AL, Bennett S, King P, Chandran S, Nag S, Chen S, Rees Smith B, Isaacs JD \& Vaidya B. Adrenal steroidogenesis following B lymphocyte depletion therapy in new onset Addison's disease. Journal of Clinical Endocrinology and Metabolism 201297 e1927-32. (https://doi.org/10.1210/jc.2012-1680)

36 Napier C, Gan EH, Mitchell AL, Gilligan LC, Rees DA, Moran C, Chatterjee K, Vaidya B, James RA, Mamoojee Y et al. Residual adrenal function in autoimmune Addison's disease-effect of dual therapy with rituximab and depot tetracosactide. Journal of Clinical Endocrinology and Metabolism 2020105 e1250-9. (https://doi. org/10.1210/clinem/dgz287)

37 The Diabetes Control and Complications Trial Research Group. Effect of intensive therapy on residual beta-cell function in patients with type 1 diabetes in the Diabetes Control and Complications Trial. A randomized, controlled trial. Annals of Internal Medicine 1998128 517-523. (https://doi.org/10.7326/0003-4819-128-7-19980401000001)

38 Lachin JM, McGee P, Palmer JP \& DCCT/EDIC Research Group. Impact of C-peptide preservation on metabolic and clinical outcomes in the Diabetes Control and Complications Trial. Diabetes 201463 739-748. (https://doi.org/10.2337/db13-0881)

39 Bouguen G, Dubuquoy L, Desreumaux P, Brunner T \& Bertin B. Intestinal steroidogenesis. Steroids 2015103 64-71. (https://doi. org/10.1016/j.steroids.2014.12.022)

40 Talabér G, Jondal M \& Okret S. Extra-adrenal glucocorticoid synthesis: immune regulation and aspects on local organ homeostasis. Molecular and Cellular Endocrinology 2013380 89-98. (https://doi.org/10.1016/j.mce.2013.05.007)

Received 6 August 2020

Revised version received 8 November 2020

Accepted 8 December 2020 